\title{
PEMODELAN REGRESI BERGANDA UNTUK DATA DALAM STUDI KECERDASAN EMOSIONAL
}

\author{
Hasan Basri \\ hasan.basri@gmail.com \\ Program Studi Pendidikan Islam Anak Usia Dini \\ Institut Agama Islam Negeri (IAIN) Bone
}

\begin{abstract}
Regression analysis is frequently used to study forecasting and relation between some variables. In studying forecasting and relation between some variables using regression, needed the best model. This research aim to multiple regression modelling for data in emotional intelligence studies and applied to the case for identified of factors influence the student emotional intelligence in Institut Agama Islam Negeri Bone. The research objective was knowledge the best regression linear model and factors influence to the emotional intelligence. The results showed the best regression linear model to knowledge influence factors of the student emotional intelligence in Institut Agama Islam Negeri Bone is, $\widehat{\boldsymbol{Y}}_{i}=77.6+0.468 X_{1 i}+0.295 X_{2 i}+0.35 X_{3 i}$. Based on this model, imagination, cognition, and personalityis significant influence to the emotional intelligence.
\end{abstract}

Keywords: Multiple regression, emotional intelligence, imagination, cognition, personality.

\section{PENDAHULUAN}

Analisis regresi merupakan suatu proses statistik untuk mengestimasi hubungan antara variabel-variabel, yakni berupa teknik-teknik memodelkan dan melakukan analisis beberapa variabel atas dasar bentuk hubungan antara satu variabel tak bebas dan satu atau lebih variabel bebas (prediktor) (Amstrong, 2012:689). 
Model atau persamaan regresi untuk populasi secara umum dapat dipostulasikan sebagai berikut:

$\mu_{\mathrm{y} . \mathrm{x} 1, \mathrm{x} 2, \ldots, \mathrm{xk}}=\mathrm{f}\left(\mathrm{X}_{1}, \mathrm{X}_{2}, \ldots, \mathrm{X}_{\mathrm{k}} \mid \theta_{1}, \theta_{2}, \ldots, \theta_{\mathrm{m}}\right)$

dengan $\theta_{1}, \theta_{2}, \ldots, \theta_{\mathrm{m}}$ parameter-parameter yang ada dalam regresi itu.Apabila hanya ada satu variabel bebas dalam persamaan maka disebut model regresi sederhana dan disebut regresi berganda jika ada dua atau lebih variabel bebas dengan jenis data tertentu.Menurut Widarjono, ada tiga jenis data yang seringkali digunakan dalam analisis regresi, yaitu: (1) data cross section adalah data yang dikumpulkan dalam kurun waktu tertentu dari sampel (2) data time series adalah sekumpulan observasi dalam rentang waktu tertentu yang dikumpulkan dalam interval waktu secara kontinu (3) data panel adalah data gabungan antara data cross section dengan data time series (Fathurahman \& Haeruddin, 2011:35).

Khusus pada data yang cenderung terpola, maka dalam hal ini regresi parametrik dapat diterapkan. Oleh karena itu, dalam studi tentang hubungan atau pengaruh dua atau lebih variabel bebas terhadap variabel tidak bebas, maka model regresi yang digunakan adalah model regresi linier ganda (multiple linear regression model) atau sering juga disebut dengan regresi klasik. Kemudian untuk mendapatkan model regresi linier sederhana maupun model regresi linier ganda dapat diperoleh dengan melakukan estimasi terhadap parameterparameternya menggunakan metode tertentu. Adapun metode yang dapat digunakan untuk mengestimasi parameter model regresi linier sederhana maupun model regresi linier ganda adalah dengan metode kuadrat terkecil (ordinary least square/OLS) dan metode kemungkinan maksimum (maximum likelihood estimation/MLE).

Penelitian ini bertujuan mengkaji pemodelan regresi berganda, khususnya regresi linear berganda untuk data dalam studi masalah kecerdasan emosional (emotional intelligence/EI), yaitu memodelkan faktor-faktor yang berpengaruh terhadap kecerdasan emosional mahasiswa di Institut Agama Islam Negeri (IAIN) Bone. Adapun faktor-faktor yang diduga berpengaruh terhadap kecerdasan emosional adalah imajinasi (imagination), kognisi (cognition), dan keperibadian (peronality). Kecerdasan emosional merupakansuatu intelegensi sosial yang meliputi kemampuan seseorang memantau emosi dirinya dan orang lain, memilah emosi dirinya dan orang lain, dan menggunakan informasi ini untuk menuntun pikirannya (Carrothers, 2000:457).

Kecerdasan emosional adalah salah satu hal yang sangat penting dalam mendukung kesuksesan hidup seseorang.Kecerdasan emosionalmerupakan kerjasama emosi (emotion) dan kecerdasan (intelligence), dimana emosi sebagai sumber informasi yang sangat berguna, 
dapat membantu seseorang untuk memahami dan mengarungi lingkungan sosialnya (Salovey \& Grewel, 2005:281). Oleh karena itu dalam bidang pendidikan, selain kemampuan daya pikir, kecerdasan emosional ini menjadi salah satu aspek yang sangat dipertimbangkan dalam rangka mendukung prestasi akademik seorang peserta didik.

Langkah-langkah pengkjian dalam penelitian pemodelan regresi berganda untuk data dalam masalah kecerdasan emosional ini, yang pertama adalah mempostulasikan model regresi linear secara umum. Kedua, adalah menentukan pola hubungan dengan mengestimasi parameter model regresi menggunakan teknik penyelasaian optimasi kuadrat terkecil. Kemudian yang ketiga, adalah membangkitkan data dari variabel-variabel yang terkait, yaitu kecerdasan emosional, imajinasi, kognisi, dan keperibadian dari 100 orang mahasiswa IAIN Bone. Selanjutnya, hasil dari estimasi model diterapkan pada data untuk mengetahui pola hubungan dan pengaruh imajinasi, kognisi, dan keperibadian terhadapkecerdasan emosional mahasiswa IAIN Bone.

\section{Model Regresi Linear Berganda}

Jika data hasil pengamatan $\mathrm{Y}$ terjadi karena akibat variabel-variabel bebas $\mathrm{X}_{1}, \mathrm{X}_{2}, \ldots$, $X_{k}$, maka hal ini menggunakan analisis regresi berganda. Model regresi linear ganda $Y$ atas $\mathrm{X}_{1}, \mathrm{X}_{2}, \ldots, \mathrm{X}_{\mathrm{k}}$ akan ditaksir oleh:

$$
\widehat{Y}=a_{0}+a_{1} X_{1}+a_{2} X_{2}+\ldots+a_{k} X_{k}
$$

dengan $a_{0}, a_{1}, a_{2}, \ldots a_{k}$ merupakan koefisien-koefisien yang harus ditentukan berdasarkan data hasil pengamatan.

Persamaan 2.1 berisikan $\mathrm{k}+1$ buah koefisien, sehingga apabila koefisien-koefisien $\mathrm{a}_{0}$, $\mathrm{a}_{1}, \mathrm{a}_{2}, \ldots \mathrm{a}_{\mathrm{k}}$ ditentukan dengan metode kuadrat terkecil, maka diperlukan penyelesaian sistem persamaan yang terdiri atas $\mathrm{k}+1$ buah persamaan. Koefisien-koefisien tersebut disebut koefisien regresi parsil, karena hanya memberikan gambaran parsil apa yang terjadi pada $\mathrm{Y}$ untuk perubahan X yang berhubungan dengan koefisien dimaksud. Pengujian signifikansi koefisien-koefisien regresi secara parsil akan digunakan statistik uji berdistribusi t (student), sedangkan secara menyeluruh (simultan) akan menggunakan statistik uji berdistribusi $\mathrm{F}$ (fisher) dengan kritikal error $\alpha=0,05$ atau derajat kepercayaan $1-\alpha=0,95$.

\section{Metode Kuadrat Terkecil untuk Regresi}

Model regresi berganda dipostulasikan seperti berikut,

$$
y_{i}=\beta_{0}+\beta_{1} x_{i 1}+\beta_{2} x_{i 2}+\cdots+\beta_{k} x_{i k}+\varepsilon_{i}(i=1,2, \cdots, n \text { dan } n \geq k+1)
$$


dengan ${ }^{y_{i}}$ adalah nilai variabel respon $\mathrm{Y}$ untuk amatan ke-i; $x_{i 1}, x_{i 2}, \cdots, x_{i k}$ adalah nilai-nilai variabel bebas $X_{1}, X_{2}, \cdots, X_{k}$ untuk amatan ke- $i ; \varepsilon_{i}$ adalah faktor galat; $\beta_{0}, \beta_{1}, \beta_{2}, \cdots, \beta_{k}$ adalah parameter koefisien regresi. Persamaan linear (2.2) dalam bentuk matriks, didefinisikan matriks-matriks berikut:

$\mathbf{y}=\left(\begin{array}{c}y_{1} \\ y_{2} \\ \vdots \\ y_{n}\end{array}\right) \mathbf{X}=\left(\begin{array}{ccccc}1 & x_{11} & x_{12} & \cdots & x_{1 k} \\ 1 & x_{21} & x_{22} & \cdots & x_{2 k} \\ \vdots & \vdots & \vdots & \ddots & \vdots \\ 1 & x_{n 1} & x_{n 2} & \cdots & x_{n k}\end{array}\right)$

$\boldsymbol{\beta}=\left(\begin{array}{c}\beta_{0} \\ \beta_{1} \\ \vdots \\ \beta_{k}\end{array}\right) \quad$ dan $\quad \boldsymbol{\varepsilon}=\left(\begin{array}{c}\varepsilon_{1} \\ \varepsilon_{2} \\ \vdots \\ \varepsilon_{n}\end{array}\right)$

Notasi matriks dari model regresi ganda adalah:

$\mathbf{y}=\mathbf{X} \boldsymbol{\beta}+\boldsymbol{\varepsilon}$

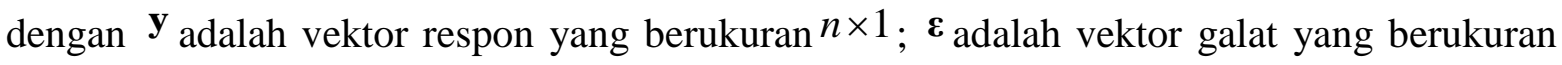
$n \times 1 ; \quad \boldsymbol{\beta}$ adalah vektor parameter regresi yang akan diduga dan berukuran $(k+1) \times 1 ; \mathbf{X}$ adalah matriks skalar yang berukuran $n \times(k+1)$ dan berpangkat penuh (Draper \& Smith, 1992:74).

Penduga kuadrat terkecil bagi $\boldsymbol{\beta}$, dinyatakan dengan $\hat{\boldsymbol{\beta}}$, adalah :

$\hat{\boldsymbol{\beta}}=\left(\mathbf{X}^{\prime} \mathbf{X}\right)^{-1} \mathbf{X}^{\prime} \mathbf{y}$.

Pembandingan dua buah penduga parameter dapat dilakukan dengan menggunakan mean square error (MSE). MSE dari suatu penduga parameter mengukur kuadrat rata-rata dari selisih antara penduga dan parameter.

Definisi 2

Mean square error dari suatu penduga $\beta_{i}^{*}$ terhadap parameter ${ }^{\beta_{i}}$ adalah fungsi dari $\beta_{i}$ yang didefinisikan oleh ${ }^{E\left[\beta_{i}^{*}-\beta_{i}\right]}$ (Draper \&Smith, 1992:78). 
Misalkan $\beta_{i}^{*}$ adalah dugaan terhadap parameter ${ }^{\beta_{i}}$. Mean square error dari $\beta_{i}^{*}$ adalah

$$
\begin{aligned}
& \operatorname{MSE}\left[\beta_{i}^{*}\right]=E\left[\beta_{i}^{*}-\beta_{i}\right]^{2} \\
& =\operatorname{var}\left[\beta_{i}^{*}\right]+\left(E\left[\beta_{i}^{*}\right]-\beta_{i}\right)^{2}
\end{aligned}
$$

MSE dari $\beta_{i}^{*}$ terdiri atas dua komponen, komponen pertama mengukur keragaman dari penduga $\beta_{i}^{*}$ dan komponen kedua mengukur bias dari penduga $\beta_{i}^{*}$. Penduga yang baik adalah penduga dengan MSE yang kecil.

\section{Varians dan Uji Hipotesis Terkait Analisis Regresi}

Untuk analisis selanjutnya tentang regresi, beberapa asumsi harus diambil. Pertama, mengingat hasil pengamatan variabel tak bebas (respon) $Y$ belum tentu sama, sehingga terjadi perbedaan yaitu,

$$
e=|Y-\hat{Y}|,
$$

biasa disebut kekeliruan prediksi atau galat prediksi. Dalam populasi, galat prediksi ini dimisalkan berbentuk variabel acak yang mengikuti distribusi normal dengan rata-rata nol dan varians $\sigma_{\varepsilon}^{2}$.

Asumsi yang kedua yang diambil adalah bahwa untuk setiap harga $X$ yang diberikan, variabel respon $Y$ independen dan berdistribusi normal dengan rata-rata $\left(\theta_{1}+\theta_{2} \mathrm{X}\right)$ untuk regresi sederhana dan $\left(\theta_{1}+\theta_{2} \mathrm{X}_{1}+\ldots+\theta_{\mathrm{k}+1} \mathrm{X}_{\mathrm{k}}\right) ; \mathrm{k}$ menunjukkan banyak variabel bebas (prediktor), dan varians $\sigma^{2}$ Y.X.

Berdasarkan asumsi-asumsi di atas, maka varians $\sigma_{\varepsilon}^{2}$ ditaksir oleh rata-rata kuadrat penyimpangan sekitar regresi atau disebut rata-rata kuadrat residual. Varians $\sigma_{\varepsilon}^{2}$ dinyatakan dengan rumus yang berbentuk seperti berikut,

$$
S_{e}^{2}=S_{Y . X}^{2}=\sum\left(Y_{i}-\hat{Y}_{i}\right)^{2} /(n-2)
$$

$\widehat{Y}_{\imath}$ adalah harga taksiran respon $Y$ hasil observasi yang diperoleh berdasarkan sampel $n$.

Untuk model regresi dengan variabel prediktor dua atau lebih, yang biasa ditaksir parameternya menggunakan rumus seperti yang ditampilkan pada persamaan (2.5), maka jumlah kuadrat regresinya adalah hasil kali dari vektor ubahan taksiran parameternya dengan matriks ubahan variabel prediktor $\mathrm{X}$ dan vektor observasi respon $\mathrm{Y}$ (Draper \&Smith, 1992:85). Dalam bentuk matriks ditulis sebagai berikut,

$$
\operatorname{JKR}(\mathbf{b})=\mathbf{b}^{\prime} \mathbf{X}^{\prime} \mathbf{Y} ; \mathrm{dk}=\mathrm{k} \text {, dan }
$$




$$
\mathrm{JKG}=\mathbf{Y}^{\prime} \mathbf{Y}-\mathbf{b}^{\prime} \mathbf{X}^{\prime} \mathbf{Y} ; \mathrm{dk}=\mathrm{n}-\mathrm{k}
$$

\section{Kecerdasan Emosional}

Kecerdasan emosional adalah kemampuan seseorang mengatur kehidupan emosinya dengan inteligensi (to manage our emotional life with intelligence); menjaga keselarasan emosi dan pengungkapannya (the appropriateness of emotion and its expression) melalui keterampilan kesadaran diri, pengendalian diri, motivasi diri, empati dan keterampilan sosial. Oleh karena itu, Carrothers dalam studinya Measuring Emotional Intelligence, membagi kecerdasan emosional dalam beberapa dimensi antara lain, kedewasaan, keharuan, kesusilaan, pergaulan, dan watak ketenangan (Carrothers, 2000:463).

Di dalam buku Emotional Intelligence, Goleman yang terinspirasi filsafat Aristoteles memberikan gambarannya tentang perihal emosi, dengan dasar beberapa respon emosional yaitu: marah, kecemasan, kegembiraan, cinta, kejutan, kemuakan/kebencian, dan kesedihan.

Kompetensi kesadaran pribadi adalah kemampuan individu dalam mengenali emosi, yang menurut mekanisme neurologi merupakan refleksi kemampuan manusiawi dan merupakan nilai tambah dari performa seseorang. Oleh karena itu, Goleman berpandangan yang sama dengan Mayer, bahwa komponen utama kecerdasan emosional adalah kesadaran emosional (emotional self-awareness). Pandangan ini merupakan implikasi atas kritik sekaligus usulan tentang bagaimana orang bisa belajar dengan baik untuk membangun kekuatan dalam suatu rentang (range) kecerdasan emosional. Hal ini pula menjadi penjelasan adanya keterkaitan antara hasil kerja otak dengan perilaku yang tampak.

\section{Imajinasi, Kognisi, dan Keperibadian}

Dalam penelitian ini, ada tiga variabel yang diduga berkaitan dan memberikan efek terhadap variasi kecerdasan emosional yaitu tingkat imajinasi, kognisi, dan keperibadian.

Imajinasi secara umum, adalah kekuatan atau proses menghasilkan citra mental dan ide. Imajinasi merupakan suatu gambaran (citra) yang dihasilkan oleh otak seseorang. Istilah ini secara teknis dipakai dalam psikolgi sebagai proses membangun kembali persepsi dari suatu benda yang terlebih dahulu diberi persepsi pengertian (Liang dkk, 2012:366).

Kognisi adalah kepercayaan seseorang tentang sesuatu yang didapatkan dari proses berpikir tentang seseorang atau sesuatu. Proses berpikir yang dilakukan adalah memperoleh pengetahuan dan memanipulasi pengetahuan melalui aktivitas mengingat, menganalisis, memahami, menilai, menalar, membayangkan dan berbahasa. 
Keperibadian (personality) adalah keseluruhan cara seseorang individu bereaksi dan berinteraksi dengan individu lain. Disamping itu, dalam kehidupan sehari-hari keperibadian sering diartikan sebagai ciri-ciri yang menonjol pada diri individu, seperti kepada orang yang pemalu dikenakan atribut "berkeperibadian pemalu".

\section{METODE}

Berdasarkan landasan teori yang ada serta rumusan hipotesis penelitian maka yang menjadi variabel dalam penelitian ini adalah :

1. Variabel respon $Y_{i}=$ kecerdasan emosional.

2. Variabel prediktor waktu $\mathrm{X}_{1 \mathrm{i}}=$ imajinasi.

3 Variabel prediktor waktu $\mathrm{X}_{2 \mathrm{i}}=$ kognisisi.

4. Variabel prediktor waktu $\mathrm{X}_{3 \mathrm{i}}=$ keperibadian.

Teknik yang digunakan dalam pengumpulan data lapangan adalah dengan menggunakan angket, yaitu suatu cara pengambilan data di mana data yang diperlukan dalam penelitian diperoleh melalui pernyataan atau pertanyaan tertulis yang diajukan kepada responden mengenai suatu hal.

Dalam penelitian ini digunakan cara scoring untuk kecerdasan emosional, imajinasi, kognisi, dan keperibadiandengan tipe skala interval, dengan model skala likert. Dimensi kecerdasan emosional terdiri dari aspek kesadaran emosional, pengaturan emosi, menyadari emosi orang lain, memelihara hubungan dengan orang lain.Hal ini dimaksudkan untuk mengukur tingkat (berupa angka skor) kecerdasan emosional mahasiswa IAIN Bone.

Setelah mengkaji estimasi kurva regresi dengan menggunakan metode kuadrat terkecil, dilakukan tahapan-tahapan selanjutnya, yaitu:

a. Diberikan data $\left(\mathrm{X}_{1 \mathrm{i}}, \mathrm{X}_{2 \mathrm{i}}, \mathrm{X}_{3 \mathrm{i}}, \mathrm{Y}_{\mathrm{i}}\right)$

b. Diberikan model regresi:

$$
\mu_{\mathrm{y} . \mathrm{x} 1, \mathrm{x} 2, \mathrm{x} 3}=\beta_{0}+\beta_{1} X_{1}+\beta_{2} X_{2}+\beta_{3} X_{3}
$$

c. Dengan metode kuadrat terkecil diperoleh taksiran parameter $\beta_{0}, \beta_{1}, \beta_{2}$, dan $\beta_{3}$, yaitu masing-masing $b_{0}, b_{1}, b_{2}$, dan $b_{3}$, maka diperoleh model regresi berdasarkan sampel.

d. Menyatakan bentuk regresi berdasarkan sampel sebagai berikut:

$$
\widehat{Y}=b_{0}+b_{1} X_{1}+b_{2} X_{2}+b_{3} X_{3}
$$

e. Menguji hipotesis nol untuk parameter menggunakan hasil taksirannya. 


\section{HASIL DAN PEMBAHASAN}

Variabel yang dianggap berpengaruh atau variabel prediktor adalah imajinasi, kognisi, dan keperibadian yang masing-masing disimbolkan dengan $X_{1}, X_{2}$, dan $\mathrm{X}_{3}$,sedangkan variabel yang dipengaruhi atau responnya adalah kecerdasan emosional (Y). Eksplorasi data untuk melihat pola kecenderungan variabel bergantung $\mathrm{Y}$ atas variabel bebas $\mathrm{X}_{1}, \mathrm{X}_{2}$, dan $\mathrm{X}_{3}$ disajikan seperti berikut.

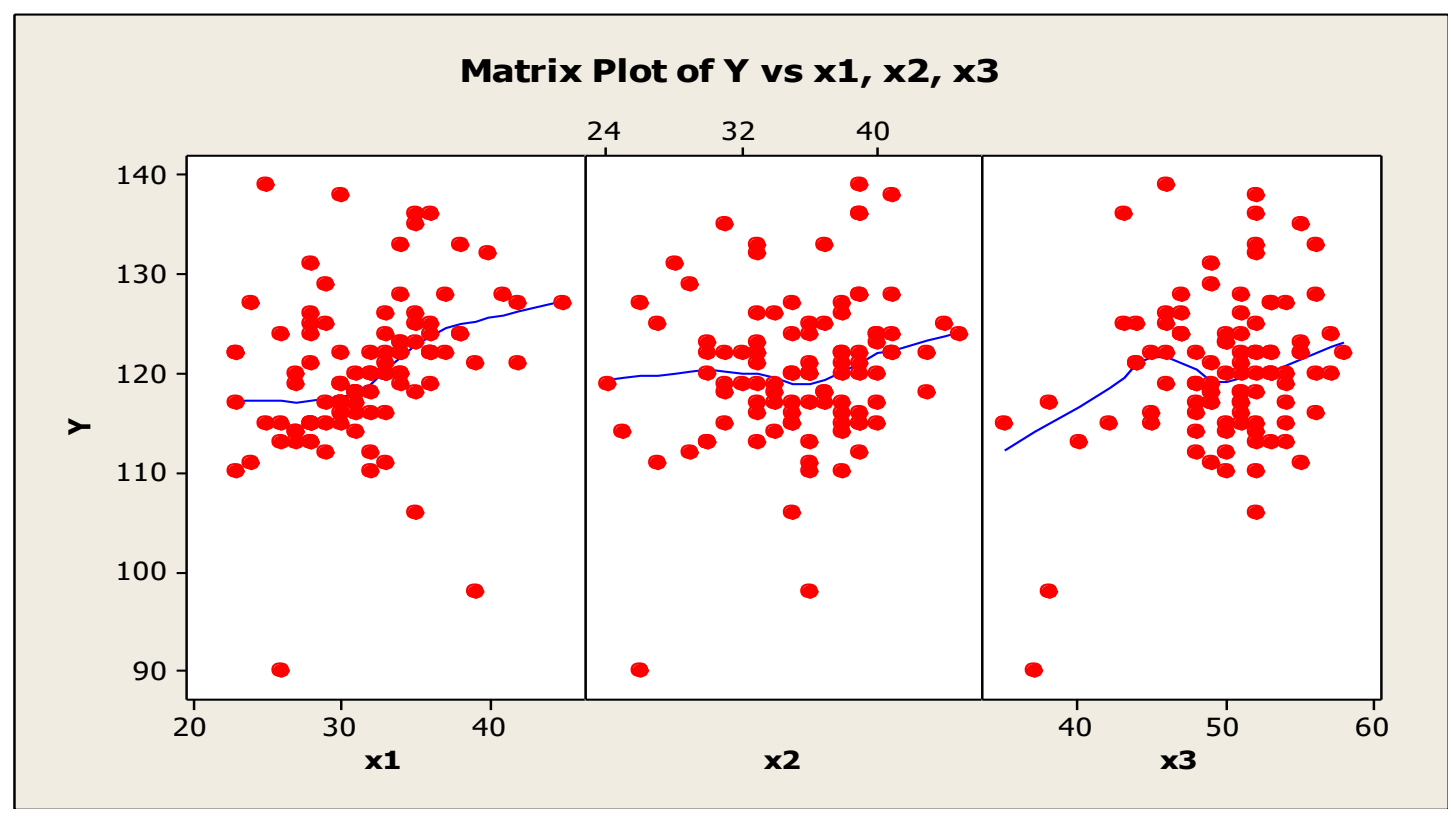

Menurut matriks plot data, ada kecenderungan pola yang linear antara tingkat daya imajinasi, kognisi, dan keperibadian dengan kecerdasan emosional. Dalam hal ini, kurva penghalus pada matrik plot data menunjukkan trend menaik. Sehingga, dalam mempelajari hubungan ketergantungan variabel-variabel, dapat dipostulatkan model linear sebagai berikut,

$Y=\beta_{0}+\beta_{1} X_{1}+\beta_{2} X_{2}+\beta_{3} X_{3}+\varepsilon$

dengan

Y : tingkat kecerdasan emosional (diasumsikan bersifat random)

$\mathrm{X} 1$ : tingkat daya imajinasi

$\mathrm{X} 2$ : tingkat daya kognisi

X3 : tingkat kualitas keperibadian

$\varepsilon:$ sisaan/galat

$\beta_{0}, \beta_{1}, \beta_{2}$, dan $\beta_{3}$ : parameter yang tidak diketahui nilainya.

Dengan menggunakan metode kuadrat terkecil, nilai dugaan (estimasi) bagi $\beta_{0}, \beta_{1}, \beta_{2}$, dan $\beta_{3}$ masing-masing adalah $b_{0}, b_{1}, b_{2}, b_{3}$, sehingga model yang dipostulatkan di atas dapat 
diestimasi menggunakan data yang telah diberikandan dinyatakan dalam bentuk persamaan sebagai berikut.

$Y_{i}=b_{0}+b_{1} X_{1}+b_{2} X_{2}+b_{3} X_{3}+e$

atau

$\widehat{Y}_{i}=b_{0}+b_{1} X_{1 i}+b_{2} X_{2 i}+b_{3} X_{3 i}$

Estimasi dengan menggunakan notasi matriks dalam kerangka kerja metode kuadrat terkecil (menggunakan Minitab), diperoleh hasil dugaan persamaan regresi, sebagai berikut $\widehat{Y}_{i}=77.6+0.468 X_{1 i}+0.295 X_{2 i}+0.350 X_{3 i}$ dengan $\widehat{Y}_{i}$ merupakan nilai prediksi $Y_{i}$ pada nilai $X_{1 \mathrm{i}}, X_{2 \mathrm{i}}$, dan $\mathrm{X}_{3 \mathrm{i}}$ tertentu; $\mathrm{i}=1,2, \ldots, 100$.

Kesesuaian persamaan regresi di atas, dapat ditunjukkan dengan menggunakan tabel anava yang menyertakan sumber variasi ketidakpasan model (lack of fit) dan galat murni (pure error) sebagai berikut,

$\begin{array}{lrrrrr}\text { Analysis of Variance } & & & & \\ \text { Source } & \text { DF } & \text { SS } & \text { MS } & \text { F } & \text { P } \\ \text { Regression } & 3 & 944.88 & 314.96 & 6.62 & 0.000 \\ \text { Residual Error } & 96 & 4570.51 & 47.61 & & \\ \quad \text { Lack of Fit } & 95 & 4498.51 & 47.35 & 0.66 & 0.779 \\ \quad \text { Pure Error } & 1 & 72.00 & 72.00 & & \\ \text { Total } & 99 & 5515.39 & & & \end{array}$

Dari tabel anava di atas, menyatakan bahwa nisbah RKL/RKE yang ditunjukkan oleh hasil bagi antara MS Lack of Fit dan MS Pure Error adalah 0,66 dengan p-value = $0,779>\alpha=0,05$, berarti ketidakpasan model (lack of fit) tidak nyata atau tidak signifikan. Oleh karenanya, dapat dikatakan bahwa persamaan regresi linear yang dipilih atau telah dipostulatkan adalah cukup memadai.

Menurut uji ketidakpasan model di atas, menunjukkan bahwa kelihatannya model sudah pas atau cocok, sehingga MS residual error $=47.61$ layak menjadi penaksir bagi $\sigma^{2}$ yang menyatakan varians amatan $\mathrm{Y}$ yang sama dengan varians error atau galat. Dengan demikian, uji-F untuk keberartian regresi dapat dilanjutkan. Hal ini juga berarti bahwa galat yang bersumber dari bias tidak ada.

Nisbah F=RKR/RKG yang dinyatakan oleh rasio MS regression dan MS residual error adalah 6,62 dengan nilai $\mathrm{P}$-value $=0,000$. Oleh karena, nilai $\mathrm{P}$-value lebih kecil dari nilai kritikal error $\alpha=0,05$ maka dapat dikatakan bahwa persamaan regresi $\widehat{Y}_{i}=77.6+0.468$ 
$\mathrm{X}_{1 \mathrm{i}}+0.295 \mathrm{X}_{2 \mathrm{i}}+0.350 \mathrm{X}_{3 \mathrm{i}}$ adalah signifikan, sehingga koefisien-koefisiennya secara bersama-sama juga signifikan.

Pengujian signifikansi koefisien regresi secara parsial, dalam hal ini digunakan uji-t. Dari análisis data diperoleh persamaan regresi sebagai berikut, $Y=77.6+0.468 X_{1}+0.295 X_{2}+0.350 X_{3}$

$\begin{array}{lrrrr}\text { Predictor } & \text { Coef } & \text { SE Coef } & \text { T } & \text { P } \\ \text { Constant } & 77.58 & 10.12 & 7.67 & 0.000 \\ \text { x1 } & 0.4684 & 0.1527 & 3.07 & 0.003 \\ \text { x2 } & 0.2951 & 0.1620 & 1.82 & 0.072 \\ \text { x3 } & 0.3495 & 0.1578 & 2.21 & 0.029 \\ & & & & \\ \text { S }=6.89997 & R-S q=17.1 \% & R-S q(\operatorname{adj})=14.5 \%\end{array}$

Hasil estimasi di atas menunjukkan bahwa, secara parsial atau terpisah semua koefisien regresi signifikan (koefisien $X_{2}$ hanya signifikan pada taraf $\alpha=0,075$ ). Pada persamaan regresi ini, standar deviasi s $=6,89997$ dapat dijadikan sebagai penaksir dari standar deviasi amatan $\mathrm{Y}$, dimana hanya terdapat 17,1 \% variasi respon $\mathrm{Y}$ yang dapat terjelaskan oleh variabel bebas $\mathrm{X}_{1}, \mathrm{X}_{2}$, dan $\mathrm{X}_{3}$.

Berdasarkan uji signifikan koefisien regresi di atas, maka dapat dikatakan bahwa terdapat secara nyata hubungan kebergantungan (dependensi) $\mathrm{Y}$ atas $\mathrm{X}_{1}, \mathrm{X}_{2}$, dan $\mathrm{X}_{3}$. Dengan kata lain, secara bersama-sama imajinasi, kognisi, dan keperibadian berpengaruh nyata terhadap kecerdasan emocional mahasiswa di IAIN Bone. Dari uji parsial, diketahui bahwa seacara sendiri-sendiri faktor imajinasi, kognisi, dan keperibadian masing-masing berkontribusi terhadap kecerdasan emosional mahasiswa, namun kelihatannya yang paling dominan adalah faktor imajinasi.

Pemeriksaan sisaan karena regresi $\mathrm{Y}$ atas $\mathrm{X}_{1}, \mathrm{X}_{2}$, dan $\mathrm{X}_{3}$ dilakukan dengan menggunakan histogram sebagai berikut. 


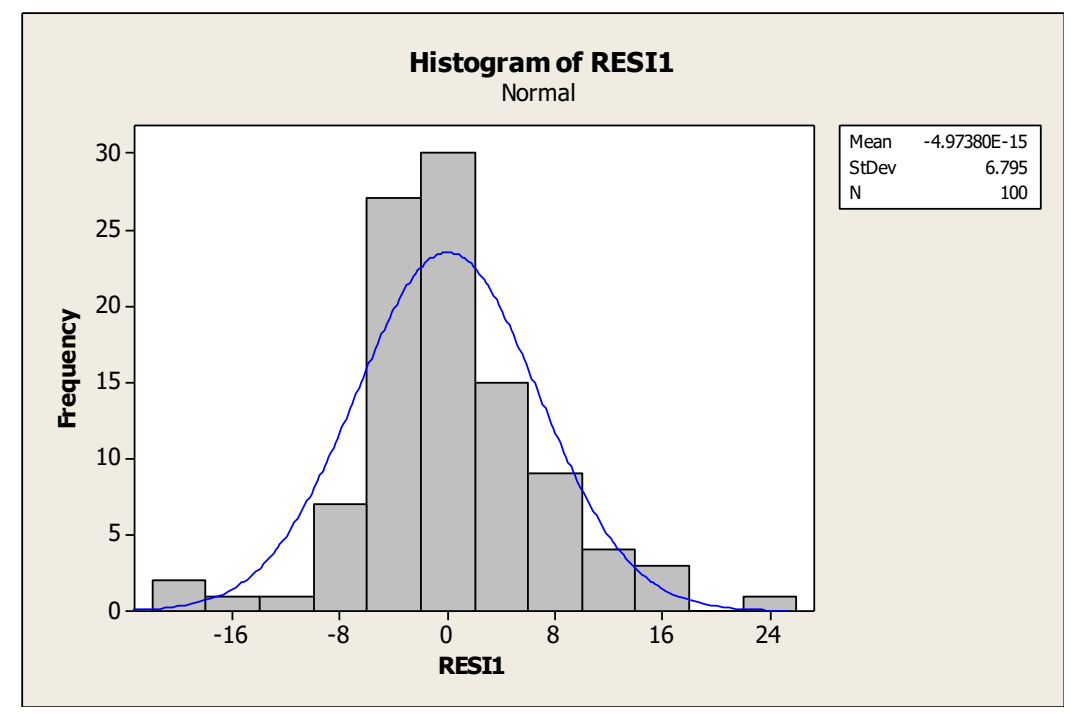

Dari kurva penghalus yang simetris diperlihatkan bahwa galat atau sisaan cenderung mengikuti distribusi normal dengan rata-rata bisa dikatakan nol, serta standar deviasi 6,795.

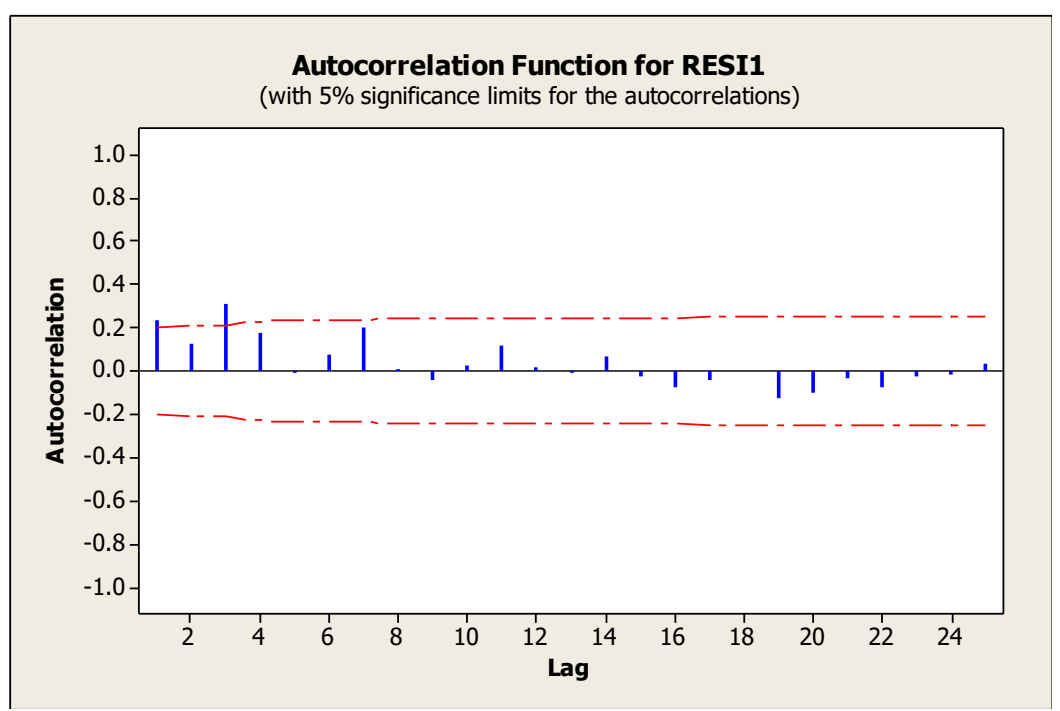

Plot acf di atas menunjukkan bahwa semua lag (kecuali lag 3) tidak ada yang keluar dari batas garis putus-putus, yang berarti bahwa error-error tidak saling berkorelasi secara nyata.

\section{KESIMPULAN}

1. Diberikan data $\left(X_{1 i}, X_{2 i}, \ldots, X_{k i}, Y_{i}\right), i=1, \ldots, n$, yang diasumsikan mengikuti model regresi parametrik, $Y_{i}=\beta_{0}+\beta_{1} X_{1 i}+\beta_{2} X_{2 i}+\ldots+\beta_{\mathrm{k}} X_{k i}+\varepsilon_{i}$, maka jumlah kuadrat semua error dalam model adalah,

$$
\begin{aligned}
\mathrm{S}=\Sigma \varepsilon_{\mathrm{i}}^{2} & =\Sigma\left(\mathrm{Y}_{\mathrm{i}}-\left(\beta_{0}+\beta_{1} \mathrm{X}_{1 \mathrm{i}}+\beta_{2} \mathrm{X}_{2 \mathrm{i}}+\ldots+\beta_{\mathrm{k}} \mathrm{X}_{\mathrm{ki}}\right)\right)^{2} \\
& =\Sigma\left(\mathrm{Y}_{\mathrm{i}}-\beta_{0}-\beta_{1} \mathrm{X}_{1 \mathrm{i}}-\beta_{2} \mathrm{X}_{2 \mathrm{i}}-\ldots-\beta_{\mathrm{k}} \mathrm{X}_{\mathrm{ki}}\right)^{2}
\end{aligned}
$$


Dengan nilai dugaan $\beta_{0}, \beta_{1}, \beta_{2}, \ldots, \beta_{\mathrm{k}}$ adalah masing-masing $\mathrm{b}_{0}, \mathrm{~b}_{1}, \mathrm{~b}_{2}, \ldots, \mathrm{b}_{\mathrm{k}}$, dapat dengan mudah diperoleh melalui notasi matriks. Sehingga dalam notasi matriks didefinisikan,

$$
\mathbf{X}=\left[\begin{array}{ccccc}
1 & x_{11} & x_{21} & \ldots & x_{k 1} \\
1 & x_{12} & x_{22} & \ldots & x_{k 2} \\
\vdots & \vdots & \vdots & \ldots & \vdots \\
1 & x_{1 i} & x_{2 i} & \ldots & x_{k i} \\
\vdots & \vdots & \vdots & \ldots & \vdots \\
1 & x_{1 n} & x_{2 n} & \ldots & x_{k n}
\end{array}\right], \mathbf{b}=\left[\begin{array}{c}
b_{0} \\
b_{1} \\
\vdots \\
b_{j} \\
\vdots \\
b_{k}
\end{array}\right], \mathbf{e}=\left[\begin{array}{c}
e_{1} \\
e_{2} \\
\vdots \\
e_{i} \\
\vdots \\
e_{n}
\end{array}\right], \text { dan } \mathbf{Y}=\left[\begin{array}{c}
y_{1} \\
y_{2} \\
\vdots \\
y_{i} \\
\vdots \\
y_{n}
\end{array}\right]
$$

dimana series data $\mathrm{i}=1,2, \ldots, \mathrm{n}$ dan koefisien $\mathrm{j}=0,1, \ldots, \mathrm{k}$. Dari hasil optimalisasi minimum jumlah kuadrat error diperoleh vektor $\mathbf{b}=\left(\mathbf{X}^{\prime} \mathbf{X}\right)^{-1} \mathbf{X}^{\prime} \mathbf{Y} ; \mathbf{b}$ adalah matriks berordo $(\mathrm{k}+1)$ x 1 yang menunjukkan koefisien-koefisien regresi yang merupakan penduga dari parameter yang diestimasi melalui metode kuadrat terkecil. Pembuktian secara teoritismenunjukkan, bahwa pendugaan kuadrat terkecil ini dapat dikatakan bersifat linear terbaik dan tak bias atau BLUE (best linear unbiased estimator).

2. Berdasarkan uji signifikan koefisien regresi, maka dapat dikatakan bahwa terdapat hubungan kebergantungan (dependensi) $\mathrm{Y}$ atas $\mathrm{X}_{1}, \mathrm{X}_{2}$, dan $\mathrm{X}_{3}$ secara nyata/signifikan. Dengan kata lain, secara bersama-sama imajinasi, kognisi, dan keperibadian berpengaruh nyata terhadap kecerdasan emosional mahasiswa di IAIN Bone. Dari uji parsial, diketahui bahwa secara sendiri-sendiri faktor imajinasi, kognisi, dan keperibadian masing-masing berkontribusi terhadap kecerdasan emocional mahasiswa, namun kelihatannya yang paling dominan adalah faktor imajinasi.

\section{DAFTAR PUSTAKA}

Amstrong,Scott J. 2012. Illusion in Regression Analysi, International Journal Forecasting, Vol. 28, 689-693.

Carrothers, Robert M. 2000. Measuring Emotional Intelligence of Medical School Applicats, Academic Medicine, Vol. 75, 456-463.

Cherniss, C. \& Extein, M. 2006. Emotional Intelligence: What Does the Research Really Indicate", Educational Psychologist, Vol. 4, 240-256.

Cherniss, C. \& Goleman, D. 2001. The Emotionally Intelligent Workplace: How to Select for, Measure, and Improve Emotional Intelligence in Individuals, Groups, and Organizations. San Francisco: John Wiley \& Sons.

Draper, N. R., dan Smith, H. 1992. Analisis Regresi Terapan, Edisi Kedua (terjemahan). Jakata: PT Gramedia Pustaka Utama.

Gerungan, W., A. 2009. Psikologi Sosial, Bandung: PT. Refika Aditama. 
Goleman, Daniel. 2000. Emotional Intelligence (terjemahan). Jakata: PT Gramedia Pustaka Utama.

-------. 2000. Working With Emotional Intelligence (terjemahan). Jakarta: PT. Gramedia Pustaka Utama.

Gottman, John. 2001. Kiat-kiat Membesarkan Anak yang Memiliki Kecerdasan Emosional (terjemahan). Jakarta: PT Gramedia Pustaka Utama.

Gujarati, Damodar N. 2003. Basic Econometric.New York: McGraw-Hill Companies, Inc.

Horton, A. MacNeill \& Wedding, Danny. 2008. Neuropsychology. New York: Springer.

Huges, M., Thompson, Henry L., \& Terrel, J. B. 2009. Developing Emotional and Social Intelligence. San Francisco: Fpeiffer An WileyImprint.

Irwanto. 1997. Psikologi Umum. Jakarta: PT. Gramedia Pustaka Utama.

Jr., Richard J. Heuer. 1999. Psychology of Intelligence Analysis. Washington, DC: Center for the Study of Intelligence, CIA.

Lewin, Kurt. 1948. Resolving Social Conflicts. New York: Harper and Brothers.

Liang, Chaoyun dkk. 2012. The Exploration of Indicators of Imagination, The Turkish Online Journal of Educatiobal Technology, Vol. 2, 364-379.

Ma, Baoyu. 2014. Philosophy of Science and Technology Education Based on Linear Regression Theory, Journal of Chemical and Pharmaceutical Research, Vol. 6, 1416-1419.

McPheat, Sean. 2010. Emotional Intelligence. London: MTD Training \& Ventus Publishing Aps.

Myers, David G. 2010. Psychology. Washington DC: Worth Publisher.

Mayer, John D.dkk. 2008. Emotional Intelligence: New Ability or Electic Traits, American Psychological Association, vol. 63, 503-521.

2004. Emotional Intelligence: Theori, Findings, and Implications, Psychological Inquiry, vol. 15, 197-215.

Mudzakir, Ahmad. 1997. Psikologi Pendidikan. Bandung: Pustaka Setia.

Mutijah. 2007. Prospek Statistik Nonparametrik Metode Brown-Mood dalam Pendidikan Tinggi: Suatu Aplikasi dalam Analisis Regresi Linier Sederhana, Insania, vol. 12, 369-387.

Nasution, Andi Hakim. 2002. Pola Induksi Seorang Eksperimentalis, Bogor: IPB Press.

Pillay, Anand. 2010. Model Theory”, Indian Council of Philosophical Research, vol. 27, 127-141

Rawlings, John O. 1989. Pantula, Sastry G., dan Dickey, David A. Applied Regression Analysis: a Research Tool. New York: Springer-Verlag New York, Inc.

Riyanto, Yatim. 2001. Metodologi Penelitian Pendidikan.Cet. Kedua. Surabaya: Penerbit SIC.

Saifuddin, Azwar. 1997. Reliabilitas dan Validitas. Yogyakarta: Pustaka Balajar Offset.

Salovey, Peter \& Grewal, Daisy. 2005. The Science of Emotional Intelligence, American Psychological Society, vol. 14, 281-295. 
Saphiro, Lawrence E. 1998. Mengajarkan Emotional Intelligence Pada Anak. Jakarta : Gramedia.

Sudjana. 2002. Metoda Statistika. Bandung: Tarsito.

Sudjana, Nana. 2001. Penilaian Hasil Proses Belajar Mengajar. Cet. ketujuh. Bandung: PT Remaja Rosdakarya.

Suryabrata, Sumadi. 1998. Psikologi Pendidikan. Jakarta: PT. Raja Grafindo Persada.

Syah, Muhibbin. 2000. Psikologi Pendidikan dengan Suatu Pendekatan baru. Bandung: PT. Remaja Rosdakarya.

Talibo, Ishak W. 2008. Membangun Kecerdasan Emosional dalam Pespektif Pendidikan Islam, Iqra', vol. 5, 13-29.

Tim Penyusun Kamus Pusat Bahasa. 2008. Kamus Bahasa Indonesia. Jakarta: Departemen Pendidikan Nasional.

Tjundjing, Sia. 2001. Hubungan Antara IQ, EQ, dan QA dengan Prestasi Studi Pada Siswa SMU, Jurnal Anima, vol. 17, 64-79.

Winkel, WS. 1997. Psikologi Pendidikan dan Evaluasi Belajar. Jakarta: Gramedia.

Wirawan, Sarlito. 1997. Psikologi Remaja. Jakarta: PT. Raja Grafindo Persada. 